\title{
An auditive protection for professional musicians
}

\author{
Paula Emanuela Fernandes Cândido ${ }^{\text {a1 }}$, Eugenio Andrés Díaz Merino a and Leila Amaral Gontijo ${ }^{a}$. \\ ${ }^{a}$ Federal University of Santa Catarina. Technological Center. Department of Production Engineering and \\ Systems. Coordination of the Post-Graduate Program in Production Engineering. Post Office Box 476 \\ ZIP: 88040-900. Florianópolis, SC, Brazil.
}

\begin{abstract}
The auditory channel is one of the most affected by the activity of musicians. The aim of this study was to verify the efficiency of the Monitor of Hearing In Ear regarding prevention of the hearing loss in the activity realized by musicians. This study justifies by the need to verify a possible method of protection for these professionals. It was analyzed a group of 10 musicians of a band of dance of Santa Catarina. The methods of research were questionnaires, audiometry and analysis of the technical specifications of Monitors of Hearing In Ear. The population investigated are aged between 18-56, and time in the profession between 37 and 0,4 years. The exhibition is of, roughly, 12 hours a week during the presentations, 4,5 hours a week rehearsing in group and from 1 to 8 weekly hours of isolated rehearsal. It was observed that $40 \%$ of the population presented normal hearing thresholds for left and right ear, the sensorineural hearing loss in the left ear was ascertained in $40 \%$ and $20 \%$ presented sensorineural hearing loss in both ears. The advantage of the Monitor of Hearing In Ear is that there is the blocking of the undesirable sounds, making possible a greater audible reduction, generally between 25 and $40 \mathrm{~dB}$, showing possibility to be considered a half of protection for professional musicians.
\end{abstract}

Keywords: Sound Pressure Level, Hearing Disorders, In ear monitor.

\footnotetext{
${ }^{1}$ Corresponding author. Email: paulinhaefc@hotmail.com
} 


\section{Introduction}

The human being is constantly exposed to levels of audible pressure, in minors or greater degrees. In the professional activities, increasingly comes studying means to attenuate the high level of audible pressure from equipments and processes, through the attenuation in the source of the same, like enclosure or coating acoustic in the equipment, exchange of the work place, and, in last case, uses the protective hearing, satisfied recommendation of the Norm Regulatory 15 - Activities and Operations Unhealthy (NR 15), of the Ministry of Work and Employment [1;2].

The high levels of audible pressure, previously studied in the industrial field, also reach workers of the recreational sector, that in spite of being a source of pleasure, can bring as bad consequences as the first one [2].

The ergonomics studies also are adhering to the problematic of the levels of audible pressure and acoustic comfort, as the same reach the worker so much in his place of work what out of him, since this requirement involves in physical consequences, cognitive and social, that extend in addition to the labour life [2].

These consequences are divided in auditory and extra-auditory. The examples of the first are: Sensorineural Hearing Loss by Exhibition Continued to High Levels of Audible Pressure, humming, diplacusis, temporary changes in the auditory threshold, between others. While the examples of the second are divided in physics (alterations of the dream, in the respiratory rhythm, in the system circulatory, vestibular disorders, headache, stomach problems, riots hormonal and neurological), cognitive (disorders of behavior and of communication, irritability, alterations in the attention and concentration, mental fatigue, stress and depression) and social (isolation, difficulties in the interaction with familiar, in the work, in the leisure and fault of social interest) $[3 ; 4 ; 5 ; 2 ; 6 ; 7$; 8].

The professional musicians are exposed to high levels of audible pressure routinely, in his places of presentation and essay, and, by times, in his isolated studies. Mainly in the presentations, the methods to attenuate the level of audible pressure described up, are not applicable or of easy acceptance, as there is not like reducing the noise in the source, there is not like exchanging the place of work, and the use of protective auditory has little acceptance by part of the musicians, by the fact of the same attenuate the decibels, they distort and interfere in the audible frequency, diminishing the perception of the notes, hampering the exert of the activity [2].

The Bands of Dance are known for touching several musical styles in his presentations. Usually they do shows in weddings, graduate parties and other events, with the aim to touch music always current and dancing songs, looking for always like to his public. The musicians have to be very insightful to improvise, to deal with the public, observe the reaction of the same in front of the music that are being executed, memorize a repertory extensive, loan attention in the execution of the others musicians, amongst other [9].

Thinking in the auditory conservation of these musicians, was raised the following question: the use of the Monitor of Hearing In Ear can be an instrument of prevention of Sensorineural Hearing Loss by Exhibition Continued to High Levels of Audible Pressure and humming?

For so much, it was developed a paper with the aim to verify the efficiency of the Monitor of Hearing In Ear regarding prevention of the Sensorineural Hearing Loss by Exhibition Continued to High Levels of Audible Pressure and of the humming in the activity realized by musicians. For so much, it was used like object of study, a Band of Dance of the South of Santa Catarina, whose members participated spontaneously of examinations audiometry and answered to a questionnaire.

The research on this subject come being developed by the companies of Monitors of Hearings, however, little has been studied in academician environment or institutions without commercial interest.

\section{Theoretical Foundation}

\subsection{Ergonomics}

In a general concept, ergonomic is a field of study that aim to adapt the work to the man, considering him the main object of research and attention, to improve his conditions of work. It understands by work all the productive activities that wrap the human being, studying it with an approach technical partner, in other words, aiming the person, the technology and the environment, and his relations. To an ergonomist exert his activity successfully, is 
fundamental that he study and comprise all the system of work and the behavior about the same, once that both suffer interference constantly $[10$; $11]$.

According to the definition of the International Association of Ergonomics (IAE),

Ergonomics (or Human Factors) is the scientific discipline that treats of the comprehension of the interactions between the human beings and other elements of a system, and the profession that applies theories, principles, data and methods, to projects that aim optimize the well be human and the global performance of the systems [12].

On a didactic form, the ergonomic area is separated in three strands: physical ergonomic; cognitive ergonomic; and organizational ergonomic. The first one tackles characteristic ace anatomic, physiological, anthropometric and biomechanics. To second covers psychological characteristic ace, the mental processes, and the man-man and mamsystem interaction. And, finally, the third one contemplates the organizational systems, their implications, rules and policy [10].

In this article will be tackled of form more specific the physical ergonomic, mainly in which respect to the anatomy and physiology of the auditory system, and its influences by the level of audible pressure.

\subsection{Hearing}

The sound arrives to the hearing system through the vibrations of the air. Anatomically, the ear is divided in three parts: external ear, medium ear and internal ear. The external ear is responsible for attracting and modify the audible wave in mechanical vibration, that is displaced until the eardrum, doing vibrate the membrane tympanic. The medium ear explain three ossicles (hammer, incude and stirrup bone) that expand the audible wave and drive this vibration. And, the internal ear transforms this mechanical vibration in hydraulic pressures, in the cochlea, where has a system of tubes spiral that echo, this vibration is captured by the ciliated cells and modified for electrical signals, that follow for the brain, by the auditory nerve. There they are decoded in audible feelings $[13 ; 14$; $10]$.

\subsection{Sound, noise and Sound Pressure Level}

The concepts of sound, noise and sound pressure level, are, by times, diffuse in the literature. The sound is produced through the vibration propagated of the molecules of air, is a variation audible of the pressure of the environment [15]. It is composed by three factors: frequency, intensity and length. The frequency is measured in Hertz $(\mathrm{Hz})$ and involves in the "number of fluctuations or vibrations by second" $[10$, p. 90], being that the low frequencies characterize the grave sound and the high frequency is the acute sound. The audible frequencies by the human beings vary of 20 to $20.000 \mathrm{~Hz}$ (twenty to twenty thousand hertz). The intensity is measured in decibel $(\mathrm{dB})$ and depends on the energy of the swings. And, finally, the measure of the length is done in seconds, where sounds down of a second are considered of short length and sounds above a second are of long length [10].

[4] defends that the concept of sound is used for pleasure feelings and noise, for sounds undesirable. [10] argues that this is the definition more common used, however is subjective, in the sense that each person has his own distinction of the that is considered desirable or undesirable. The referred author adds that "physically, the noise is a complex mix of diverse vibrations, measuring in a logarithmic scale, whose unit is decibel (dB)" [10, p. 504]. Already [5] relates that the noise is an acoustic signal aperiodic, and the sound undesirable is called of confusion.

For $[15$, p. 5], "sound is the feeling produced in the auditory system; and noise is a sound without harmony, in general of connotation negative". In accordance with the referred author, the intense noise elevates the level of audible pressure and can cause auditory loss, justifying the name of the riot.

[2], in her thesis, consider the concept of high levels of audible pressure to refer to levels harmful for the auditory system.

For legislative purposes, NR 15, of the Brazilian Ministry of Work and Employment, employs the noise as being unhealthy. The NR 7 - Programs of Medical Control and Occupational Health and the National Institute of Security Social, in the Order of Service 608, attribute the concept of high levels of audible pressure, to define the occupational auditory loss $[16 ; 17]$. In all the study realized with sound / noise / level of audible pressure, has to carry in account the characteristic physics of the environment, as his form, the material of the environment built, etc. [5].

\subsection{Hearing Alterations}


The prolonged exhibition to high levels of audible pressure can involve in sensorineural hearing loss, this can be temporary or permanent [15]. The temporary auditory loss is an alteration in the auditory threshold that, after some time of rest, recovers [18]. In the temporary alterations of the auditory threshold...

...They occur discreet intracellular alterations, edema of the nerve terminals beside the ciliated cells, vascular alterations, chemical and exhaustion metabolic, in addition to the decrease of the rigidity of the stereocilia, that causes, a reduction in the capacity of the cells to perceive the audible energy that reaches them and, consistently, alteration of his sensitivity. [4, p. 35].

Diverse factors can contribute for the appearance of these alterations, like the time of exhibition, intensity, frequency of the noise and sensitivity of the individual. The necessary time so that the hearing system recover is greater that of the auditory fatigue, being able to carry hours [4].

The humming is a feeling of sound in one or in the two ears, however without audible stimulus. He is seen like a temporary alteration, when it appears immediately after the exhibition to an intense noise, being able to be during the working time, and ceasing after the rest. However, when the time of exhibition prolongs, the humming can need increasingly of a greater time of rest to disappear, being able to, included, do permanent. The permanent hearing alterations more common studied are: sensorineural hearing loss, difficulty of the communication and feeling of fullness in the ear [4].

According to [16], the auditory loss by levels of audible pressure elevated is characterized for being sensorineural, have occurred by systematic occupational exhibition, be irreversible, have gradual progression and occur, usually, in the band of frequency of 3 to $6 \mathrm{kHz}$. The hearing loss generally has start in the frequencies of 6,4 or 3 $\mathrm{kHz}$, and generally no lowers $40 \mathrm{~dB}$, in the low frequencies, and $75 \mathrm{~dB}$ in the high frequencies [4].

The auditory loss succeed when the waves vibrating reach the cells sensory external, located in the organ of Corti, in the internal ear, breaking them, and is by this reason that the injury is irreversible [4; 14]. The auditory damage caused in half industrial is designated Hearing Loss Induced by the Noise, however, when treating of musicians and radio announcer, the term adopted is Sensorineural Hearing Loss by Exhibition Continued to High Levels of Audible Pressure [15].
In the Brazilian legislation, there are two lines to delimit the exhibition to the level of audible pressure. To verify the salubrity or insalubrity of the environment of work, the NR 15 establishes like Limit of Tolerance the exhibition of $85 \mathrm{~dB}(\mathrm{~A})$ for eight daily hours. Already the NR 17 - Ergonomics, defines the limit for acoustic comfort of $65 \mathrm{~dB}(\mathrm{~A})$ [19].

The audiometric examination is "a group of necessary procedures for evaluation of the audition of the worker along the time of exhibition to the risk" $[16$, p. 8]. Not to characterize auditory loss, the auditory threshold has to be inferior or the same to $25 \mathrm{~dB}(\mathrm{~A})$ in all the frequencies. And, to characterize occupational hearing loss, the hearing threshold has to be upper to $25 \mathrm{~dB}(\mathrm{~A})$ in the frequencies of 3.000 and/or 4.000 and/or $6.000 \mathrm{~Hz}$, and more elevated in the others frequencies [16].

\subsection{Studies relating auditory loss to the activity of the professional musicians}

Some studies come relating the auditory loss and professional musicians, of between them, [8] did a research with musicians of a band pop-rock from Curitiba, with the aim to evaluate the level of audible pressure to whom five members are exposed, as well as the behavior of the most prejudiced and suggest attenuations. As result, ascertained that the drummer is the most exposed musician to the Sound Pressure Level, reaching the band of $109 \mathrm{~dB}(\mathrm{~A})$, and the other, $107 \mathrm{~dB}(\mathrm{~A})$. As suggestion, they proposed the use of protective auricular type shell or plug of insertion, both would attenuate the decibels in accordance with the limits of tolerance indicated in the NR 15, however, emphasized that aesthetically, the protective auricular type plug of insertion would be more indicated.

[20], in his study with classical musicians and of rock and jazz, came to the conclusion that the musicians that touch wooden instruments or of metal exhibit an auditory threshold slightly worse. The musicians of rock and jazz presented auditory thresholds slightly worse of that the classical musicians. It observed that $74 \%$ of the musicians of rock and jazz have some auditory riot, being that $79 \%$ were men and $63 \%$ were women. They are more common in men: hearing loss (52\%) humming (45\%) and distortion (19\%). And hyperacusis (56\%) is more common in women. $24 \%$ of the musicians had problems of distortion and $4 \%$ had diplacusis. 
The majority of these already affected musicians have some hearing problem associated, only $27 \%$ of the musicians affected have a discreet hearing deficiency.

In the study of [21], ascertained that the decision of the audiometry exam presented $78,3 \%$ of the musicians with normal auditory threshold, and $21,7 \%$ resulted falling of the hearing threshold. Even in the decisions presented with the normal auditory threshold, "had a lot of presence of notch, was joined or bilateral $(56,5 \%)$, mainly in the frequency of $6000 \mathrm{~Hz}$ " [21, p. 456].

The musicians have to use returns of sound, that are boxes of sound gone back for the stage, to be able to listen what are touching. The Monitor of Hearing In Ear acts like this return, however deletes the external noises to the stage, once that he is a phone that goes inside the auditory channel. The isolation can arrive to $34 \mathrm{~dB}(\mathrm{~A})$, protecting the auditory health of these professionals [22]. The specifications of other marks guarantee a reduction of until $40 \mathrm{~dB}(\mathrm{~A})$ in the level of audible pressure [23].

\section{Materials e Methods}

This is a study of case realized with a band of south dance of Santa Catarina, containing 10 (ten) members, with time of presentation of 12 (twelve) hours/week and essay in group of 4,5 (four comma five) hours/week.

The data collecting through an enclosed questionnaire, containing 26 (twenty-six) questions, being 19 (nineteen) questions if "yes", "no" and "frequency", related with the frequency of the exhibition to high levels of audible pressure and his consequences, and 7 (seven) questions with information referents to the age and time of exhibition to the Sound Pressure Level.

Complementing the data, was realized the examination audiometric with all the members, in a Clinic of Phonoaudiology in Criciúma, Santa Catarina, Brazil, in April of 2011. This examination places in the patterns established by the Ministry of the Work and Employment.

\section{Results e Discussion}

The population investigated is constituted by 10 (ten) professional musicians of a band of dance of the city of Criciúma, south of Santa Catarina, with ages between 18 and 56 years, with time of exhibition between 0,4 and 37 years. Between the members, eight are relatives, being four brothers and four nephews, in other words, two generations of the family, being that, previously to those, there is not historical of auditory riots. The two other members of the referred band neither possess relate of auditory riots in the family.

The time of exhibition during the presentations is of 12 hours by week, divided in three nights to finals of week, however, in some periods there is an addition in the demand, as in the summer, where there is more shows in the open air, in festive and dates commemorative. The length of the essay in group is of, roughly, 4 hours by week, being that, depending on the requirement, this time can increase. The isolated essay talks in accordance with the need of each one (Table 1).

Table 1

Members Data

\begin{tabular}{cccc}
\hline Member & Age (years) & Exposition (years) & Isolated Rehearsing (hours) \\
\hline 1 & 18 & 0,4 & 2 \\
2 & 22 & 0,6 & 5 \\
3 & 23 & 2 & 8 \\
4 & 25 & 7 & 2 \\
5 & 28 & 11 & 1 \\
6 & 31 & 12 & 2 \\
7 & 36 & 18 & 2 \\
8 & 43 & 27 & 5 \\
9 & 47 & 29 & 1 \\
10 & 56 & 37 & 3 \\
\hline
\end{tabular}

Source: Research Data 
The conclusion of the audiometric examination revealed that $40 \%$ of the musicians present hearing thresholds inside the patterns of normality, has the average of age of 22 years and the average of exhibition of 2,5 years. A population of $40 \%$ was diagnosed with sensorineural loss slight to moderate in the left ear, and has average of age of 39,25 years and average of exhibition of 21,5 years. And, $20 \%$ they obtained sensorineural hearing loss slight to moderate in the left and right ears, with average of age of 42 years and average of exhibition of 24 years (Figure 1 and Table 2).

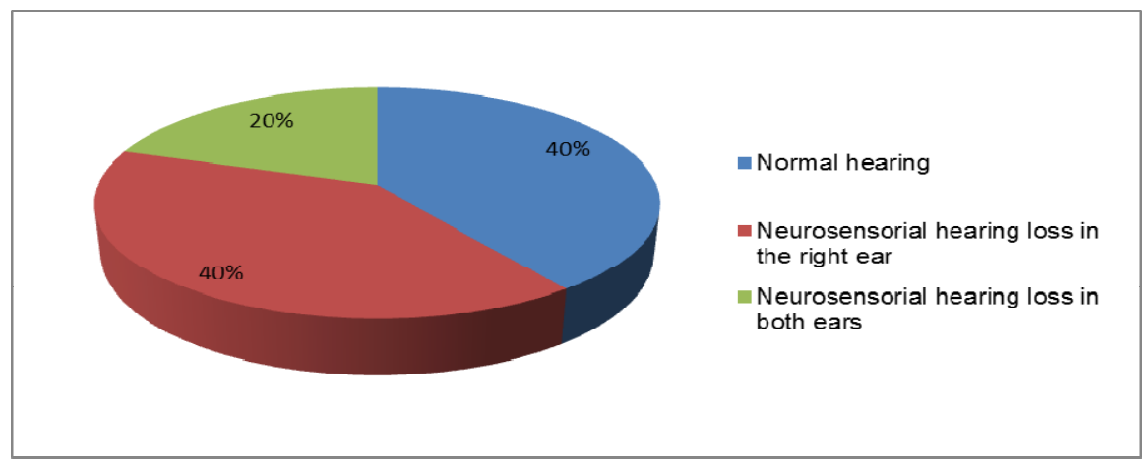

Figure.1 - Audiometric examination report. Source: Research Data

Table 2

Average Age of Exposure Time

\begin{tabular}{ccc}
\hline Population & Average Age (years) & Average Exposition (years) \\
\hline $40 \%$ & 22 & 2,5 \\
$40 \%$ & 39,25 & 21,5 \\
$20 \%$ & 42 & 24 \\
\hline
\end{tabular}

Source: Research Data

The Figure 2 represents the result of the audiometric examination of the right ear of each member.

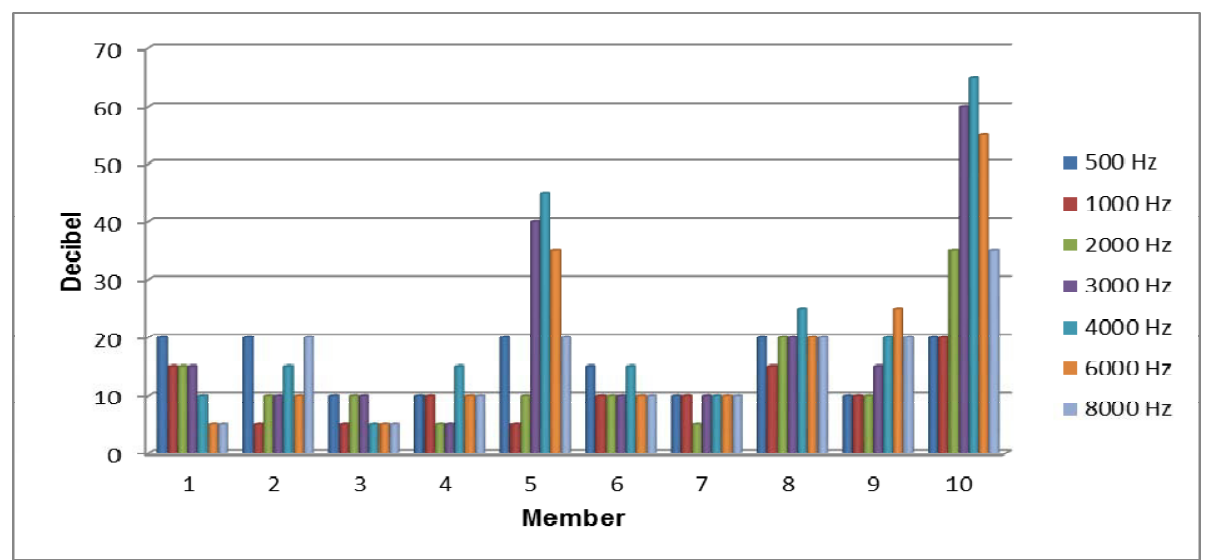

Figure 2 - Results of the audiometric examination of the right ear. Source: Research Data 
This graphic aims that there is the preponderance of hearing loss in the frequency of $4000 \mathrm{~Hz}$, being ascertained that the $20 \%$ that had in his decision sensorineural loss in both ears, had in this frequency, his hammer of damage.
The Figure 3 sample the result of the audiometric examination of the left ear by member.

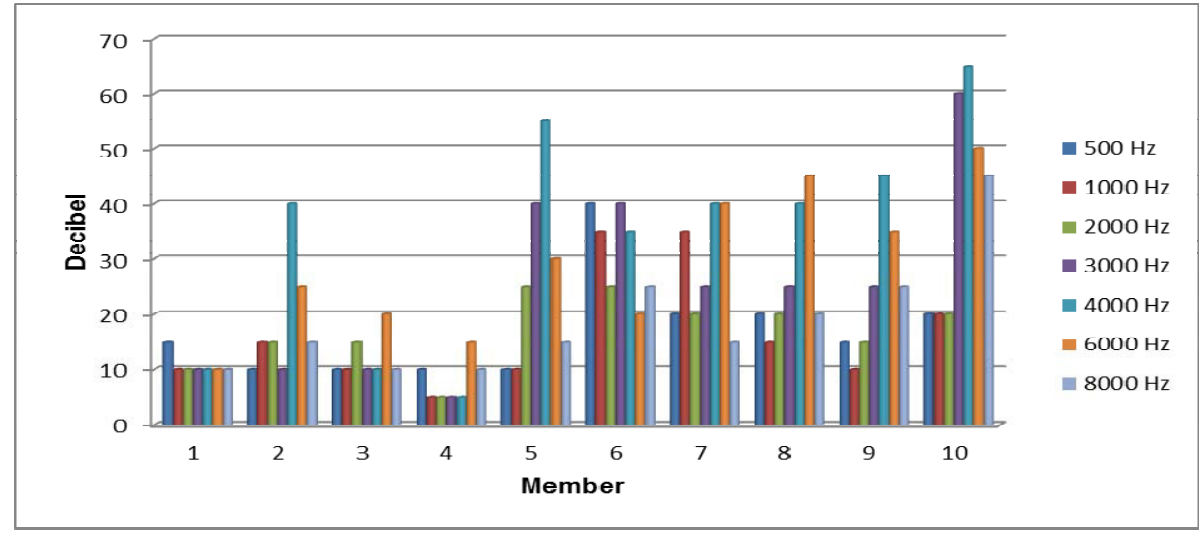

Figure 3 - Results of the audiometric examination of the left ear. Source: Research Data

As well as the previous graphic, east showed that I hammer it of hearing loss is in the frequency of $4000 \mathrm{~Hz}$, with four members having in this point his main damage. Followed of the frequency of 6000 $\mathrm{Hz}$, with three members. While $100 \%$ of the population with sensorineural hearing loss in both ears had his beak of damage in the left ear in the frequency of $4000 \mathrm{~Hz}$, the result did not repeat for the population whose decision revealed sensorineural hearing loss in the left ear, where occurred one beak of damage in the frequency of $4000 \mathrm{~Hz}$, one in the frequency of $6000 \mathrm{~Hz}$, one equalized in the frequencies of 500 and $3000 \mathrm{~Hz}$ and another in the frequencies of 4000 and $6000 \mathrm{~Hz}$ (Figure 4).

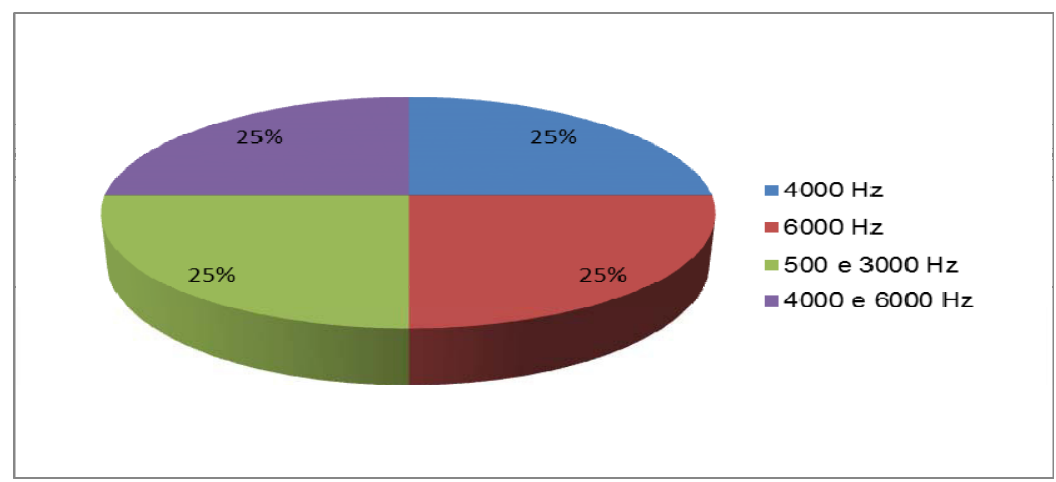

Figure 4 - Peak of the population with sensorineural hearing loss in left ear Source: Research Data

The study shows that the advance of the age and of the time of exhibition influences in the evolution of the sensorineural hearing loss, confirming the study of [4]. In the case of the musicians investigated, the left ear, in general, went of more affected, even in treating of the members that did not have decision of hearing loss.
But, a data reveals that only the two factors above are not sufficient to cause this damage in the auditory system, once that the member 5 , with age of 28 years and time of exhibition of 11 years, presented sensorineural hearing loss in the right and left ears, being that this has age and time of exhibition down of the average for each category, 
down, included, of the averages for the group that presented sensorineural hearing loss in the left ear.

Of between some habits that can influence in the hearing loss, the questionnaire on the population investigated revealed that $70 \%$ related that it accustoms to listen music or television with high intensity, being, in average 3,05 daily hours. In the group, $50 \%$ uses phones of hearing, during an average of 0,75 hours by day. And, only $20 \%$ it uses monitor of hearing In Ear during the presentations, being that the acquisition occurred 6 months ago.

With reference to other auditory problems, anybody related to suffer of diplacusis (simultaneous audition of two sounds caused by an only stimulus) and phonophobia (fear of the exhibition to the sound), $90 \%$ related not having hyperacusis (tolerance reduced to sounds, even in moderate intensity) and pain in the ear canal, the $10 \%$ remaining of each riot suffer seldom, $90 \%$ related not having difficulty to converse and $10 \%$ said to have difficulty in some times. The misophonia (emotional answer or conditioned associated to the aversion or to the unpleasure to the exhibition to some types of sounds) and feeling of fullness in the ear was related by $30 \%$, being that of these, $10 \%$ related to have few times in the two cases, 20\% suffers with misophonia some times and $20 \%$ suffers with feeling of fullness in the ear. Regarding the humming, $20 \%$ relate to feel seldom, $20 \%$ frequently and $60 \%$ do not present this picture.

In relation to the others riots, $10 \%$ suffer of headache often, $10 \%$ suffers few times, $10 \%$ seldom and $70 \%$ do not present. The physical discomfort is a frequent complaint for $10 \%$, few times for $20 \%$ and is not a complaint for $70 \%$. The physical discomfort appears frequently in $10 \%$ of the cases, some times in $20 \%$ and do not appear in $70 \%$. In the population investigated, $100 \%$ does not suffer with mental discomfort.

The Sensorineural Hearing Loss by Exhibition Continued to High Levels of Audible Pressure, for being consequence of accumulative damage, when it ceases the stimulus, she does not progress, however, the environment of work of the professional musicians does not favor to the extinction of this risk, being the only appropriate measure, the use of some equipment of protection. But, this neither is of easy resolution, since usually the protective auditory reduce the perception of the notes, hampering the execution of the music. In these cases, a solution is the use of the Monitors of Hearing In Ear, since they reduce the level of audible pressure without prejudicing the hearing acuity, necessary for a good performance.

\section{Final Considerations}

The resultant hearing loss of the exhibition to high levels of audible pressure in the environment of work is a riot that reaches a lot of classes of workers, included professional musicians. However, the preventive solutions are studied, usually, by companies that commercialise the product.

This study aimed to verify if the use of Monitor of Hearing In Ear could be a preventive equipment for the auditory loss in this class of professionals. For so much, it was realized a study with a band of dance, containing ten members, that realized audiometric examinations and answered to questionnaires. With this, could observe the influence of the age and of the time of exhibition for the hearing loss.

In accordance with the technical specifications of the Monitor of Hearing In Ear, he can be considered a solution for the prevention of the hearing loss in these professionals, however at all was related on the others auditory riots.

There is the need of a study of scientific imprint, that investigate the efficiency of these equipments, without financial commercial/interest.

Another proposal of research is investigate the case of the member 5, that had an hearing loss above the common for this group, to end to ascertain the reason of this apparition, since the same does not possess historical of auditory riots in the family and the habits are compatible with the other. 


\section{References}

[1]Brasil, Ministério do Trabalho e Emprego. Norma Regulamentadora NR15 - Atividades e Operações Insalubres. 2011a. Disponível em: < http://portal.mte.gov.br/legislacao/norma-regulamentadora-n15-1.htm>. Acesso em: 23 mai 2011.

[2] Graciolli, Lilian Seligman. Universidade Federal de Santa Catarina, Programa de Pós-Graduação em Engenharia de Produção. Análise quali-quantitativa do uso de protetores auditivos especiais em músicos. Florianópolis, $2006221 \mathrm{f}$. Tese (Doutorado) - Universidade Federal de Santa Catarina, Centro Tecnológico. Programa de Pós-Graduação em Engenharia de Produção.

[3] Carmo, Lívia Ismália Carneiro do. Centro de Especialização em Fonoaudiologia Clínica Audiologia Clínica. Curso de Especialização. Efeitos do ruído ambiental no organismo humano e suas manifestações auditivas. 1999. (Monografia).

[4] Didoné, Janete Aragones. Universidade Federal de Santa Catarina, Centro Tecnológico. Conforto oferecido por diferentes protetores auditivos. Florianópolis, 1999. $170 \mathrm{f}$. Dissertação (Mestrado) - Universidade Federal de Santa Catarina, Centro Tecnológico.

[5] Fleig, Raquel. Universidade Federal de Santa Catarina, Programa de Pós-Graduação em Engenharia de Produção. Perda auditiva induzida por ruído em motoristas de caminhão de lixo urbano. Florianópolis, 2004. 86 f. Dissertação (Mestrado) - Universidade Federal de Santa Catarina, Centro Tecnológico. Programa de Pós-Graduação em Engenharia de Produção.

[6] Martins, Alessandra. Centro de Especialização em Fonoaudiologia Clínica Audiologia Clínica. Curso de Especialização. Mudança temporária de limiar: Um estudo em cabelereiros. 2001. (Monografia).

[7] Medeiros, Luana Bernardines. Centro de Especialização em Fonoaudiologia Clínica Audiologia Clínica. Curso de Especialização. Ruído: efeitos extra-auditivos no corpo humano. 1999. (Monografia).

[8] Mendes, Márcio Henrique. CATAI, Rodrigo Eduardo. ALBERTI, Mauro Edson. Avaliação dos Níveis de Pressão Sonora aos quais Músicos de uma Banda estão Expostos. Revista Produção On Line. Vol. IX/ Num.II / 2009.

[9] Ascenção, Érico. Álbuns de Cabeceira. Sobre "Bandas de Baile" - sim, com aspas. 13 fev 2011. Disponível em: $<$ http://albunsdecabeceira.blogspot.com/ 2011/02/sobrebandas-de-baile-sim-com-aspas.html>. Acesso em: 29 abr 2011.

[10] Iida, Itiro. Ergonomia: projeto e produção. 2. ed. rev. e ampl. São Paulo: Blucher, 2005. 614 p.

[11] Fialho, Francisco. SANTOS, Neri dos. Manual de Análise Ergonômica do Trabalho. $2^{\mathrm{a}}$ ed. rev. e ampl. Curitiba: Genesis, 1997.
[12] IEA - International Ergonomics Association. Definição Internacional da Ergonomia. Ação Ergonômica. 2000

[13] Bvastri, Elizabete Yukiko Nakanishi. Universidade Federal de Santa Catarina, Programa de Pós-Graduação em Engenharia de Produção. Protetores auditivos: determinação da atenuação sonora por métodos computacionais e método objetivo. Florianópolis, 2001. 141 f. Dissertação (Mestrado) Universidade Federal de Santa Catarina, Centro Tecnológico. Programa de Pós-Graduação em Engenharia de Produção.

[14] Guyton, Arthur C. . Fisiologia humana. 6. ed. Rio de Janeiro: Guanabara Koogan, 1988. 563p.

[15] Bistafa, Sylvio R.. Acústica aplicada ao controle do ruído. São Paulo: Blucher, 2006. 368p.

[16] Brasil, Ministério do Trabalho e Emprego. Norma Regulamentadora NR7 - Programa de Controle Médico de Saúde Ocupacional. 2011b. Disponível em: < http://portal.mte.gov.br/data/files/8A7C816A2E7311D10130 04EF24CC5167/nr_07_at.pdf>. Acesso em: 23 mai 2011.

[17] Brasil, Instituto Nacional de Seguridade Social. Ordem de Serviço 608. 1998. Disponível em: < http://www.opusfonoaudiologia.com.br/site/arquivos/OS608INSS-05-08-98.pdf $>$. Acesso em: 23 maio 2011.

[18] Alves Filho, Joel Manoel. Universidade Federal de Santa Catarina, Centro Tecnológico. O ruído no ambiente de trabalho: sua influência nos aspectos biopsicossociais do trabalhador. Florianópolis, 2002. 249 f. Tese (Doutorado) Universidade Federal de Santa Catarina, Centro Tecnológico. Programa de Pós-Graduação em Engenharia de Produção.

[19] Brasil, Ministério do Trabalho e Emprego. Norma Regulamentadora NR17 - Ergonomia. 2011c. Disponível em: $<\quad$ http://portal.mte.gov.br/data/files/ FF8080812BE914E6012BEFBAD7064803/nr 17.pdf>.

Acesso em: 23 mai 2011

[20] Kähäri, Kim et al.. The influence of music and stress on musicians' hearing. Journal of Sound and Vibration. 277 (2004) 627-631.

[21] Santoni, Cristiane Bolzachini. FIORINI, Ana Claudia. Poprock musicians: Assessment of their satisfaction provided by hearing protectors. Braz J Otorhinolaryngol. 2010; 76(4):454-61. Disponível em: < http://www.scielo.br/pdf/ bjorl/v76n4/v76n4a09.pdf >. Acesso em: 19 mai 2011.

[22] Scanavino, Hugo G. Fones de Ouvido para uso em retorno. s/d. Disponível em: $<$ http://www.somaovivo.mus.br/testes.php?id=24>. Acesso em: 25 mai 2011.

$[23]$

$$
\text { Premium, }
$$

http://www.premiumaudio.com.br/Produto/Audio/Sistemasde-In-Ear/Shure/monitor-pessoal-sem-fio-in-ear-p2tr115lc1h2-fone-de-ouvido-e2-psm200-h2-shure.aspx. Acesso em: 25 mai 2011. 